\title{
Evaluation of microbial contamination level and the drug susceptible pattern of the isolates cultivated from famous dessert food
}

\author{
${ }^{1}$ Akter, T., ${ }^{1}$ Ishma, T., ${ }^{1}$ Razzeb, S.R., ${ }^{2}$ Uddin, S.H.M., ${ }^{1}$ Islam, M., ${ }^{1}$ Akhter, M., ${ }^{1}$ Saha, S., \\ ${ }^{1}$ Shomi, F.Y., ${ }^{1}$ Feroz, F. and ${ }^{1,3, *}$ Acharjee, M. \\ ${ }^{1}$ Department of Microbiology, Stamford University Bangladesh, 51 Siddeswari Road, Dhaka-1217, \\ Bangladesh \\ ${ }^{2}$ School of Medical Science, Faculty of Biology, Medicine and Health, The University of Manchester, \\ Stopford Building, Manchester, M13 9PL, United Kingdom. \\ ${ }^{3}$ Department of Bioscience, Graduate School of Science and Technology, Shizuoka University, Oya 836, \\ Suruga-ku, Shizuoka, 422-8529, Japan
}

\begin{abstract}
Article history:
Received: 19 August 2020

Received in revised form: 9

September 2020

Accepted: 30 October 2020

Available Online: 7 February 2021
\end{abstract}

Keywords:

Dessert food,

Microbial contamination,

Drug resistant

DOI:

https://doi.org/10.26656/fr.2017.5(1).452

\begin{abstract}
Present study endeavored to evaluate the microbial contamination level along with their drug resistant pattern in some popular desert food items collected from different food shops in Dhaka city, Bangladesh. The microbial evaluation was conducted through conventional cultural methods and drug susceptibility test was executed through disc diffusion method. All the samples were found to be contaminated with heterotrophic bacteria as well as fungi within the range of $10^{3}$ to $10^{5} \mathrm{CFU} / \mathrm{g}$. In case of specific microflora, the growth of Staphylococcus spp. was very high in sweet, faluda, milk cake and ice cream as estimated up to $10^{5} \mathrm{CFU} / \mathrm{g}$, halua and sweet yogurt showed $10^{4} \mathrm{CFU} / \mathrm{g}$ while rest of the samples revealed $10^{3} \mathrm{CFU} / \mathrm{g}$. E. coli was found only in faluda and ice cream up to $10^{3} \mathrm{CFU} / \mathrm{g}$ whereas Klebsiella spp. was estimated in all the samples within the range of $10^{2} \mathrm{CFU} / \mathrm{g}$ to $10^{5} \mathrm{CFU} / \mathrm{g}$. Salmonella spp., Pseudomonas spp. and Bacillus spp. were totally absent in all the samples. Most of the isolates were found to be resistant against most of the antibiotics. Meanwhile, streptomycin $(10 \mu \mathrm{g})$, gentamicin $(10 \mu \mathrm{g})$, azithromycin $(15 \mu \mathrm{g})$, and nalidixic acid $(5 \mu \mathrm{g})$ were effective drug against both $E$. coli and Staphylococcus spp.
\end{abstract}

\section{Introduction}

Dessert is a sweet confectionary, which is not only very famous in Asian people but also it has huge demand in outside of the Asia as the last test of a meal. This definition includes a range of courses ranging from fruits or dried nuts to multi-ingredient cakes and pies. Many cultures have different variation on dessert. In modern times, the variations of desserts have usually been passed down or come from geographical regions. Especially, peoples are very used to have dessert in traditional cuisines or cultural programmes. Mainly, dessert are usually formulated by milk, sugar, modified starch, hydrocolloids like carrageenan, flavorings and colorants (De Wijk et al., 2003; González-Tomás and Costell, 2006). In case of puddings, sodas, cakes, ice cream, fruits, and pastries, the food makers are preferably using the whipped toppings. Therefore, it is important to maintain the quality of the products to eliminate the rate of food spoilage as well as food borne diseases such as diarrhea, dysentery, and abdominal cramping (Danielsson-Tham et al., 2004; MacDonald et al., 2005). Several reports have been conducted earlier on the transmission of diseases causing microbes especially $E$. coli, Staphylococcus spp., Campylobacter, Klebsiella spp. Enterobacter, etc. from the dairy-based foods to the human body especially in countries where hygienic standard is not up to the satisfactory level (MeyerBroseta et al., 2003; Danielsson-Tham et al., 2004; MacDonald et al., 2005; Makino et al., 2005; Okwumabua et al., 2005; Oliver et al., 2005). The dried milk products must be stored in optimal conditions. If there is proper packaging, there will be no change in color, even during two years of storage at $35^{\circ} \mathrm{C}$. Nevertheless, in commercial situations, most dry milk products are vulnerable to reactions, which will lead to small changes within the physical properties of the merchandise, its palatability and nutritive value. These 
changes, however, do not significantly influence the nutritional benefits of milk powders. Vitamin and protein quality losses during storage of milk powders, when stored in good conditions, are negligible (U.S. Dairy Export Council, 2001). Similarly, the quality of food depends on the general number of viable organisms as revealed by the general bacterial count. However, the load of microbes in food products is influenced by the type of things just like the final environment from which the raw materials were obtained, the environment during which it had been processed, the sanitary conditions under which the food was handled and processed, and so the adequacy of processing procedures targeted at reducing contaminants during the packaging, handling and storage of the merchandise (Osamwonyi, 2005). A significant group of contaminants within the dairy industry is caused by thermophilic bacilli. However, these bacilli are generally not pathogenic, their presence in dairy products is an indicator of poor hygiene and high numbers are unacceptable to customers. Additionally, their growth may end in milk product defects caused by the assembly of acids or enzymes, potentially leading to off-flavours. Dairy thermophiles (Bacillus cereus, Listeria monocytogenes, Salmonella spp., Campylobacter jejuni) are usually selected for the conditions during dairy manufacture. For being a spore forming bacteria they are able to grow in dairy manufacturing plants where even temperatures reach 40 $65^{\circ} \mathrm{C}$.

Furthermore, the control of food contamination by microorganisms or the practice of food protection largely depends on the knowledge on types and modes of food hazards, the pathogenic trait, the virulence factors of the food contaminating bacteria and fungi, knowledge on toxins associated with food deterioration and finally the urge of practical implementation of food protection means both by the governmental or non-governmental organizations (NGOs). The main goal of the present study was to investigate the microbiological quality analysis of the dessert samples.

\section{Materials and methods}

2.1 Study area, sampling, sample processing and microbiological analysis

A total of eighteen different dessert (sweet, faluda, ice cream, pudding, halua, sweet yogurt, mango lassi, tusha haiwa, lemon curd, egg haloa, fresh cheese dessert, shemai, bread pudding, milk cake, jellow fruit custard, faluda, cake and rasmalai) were randomly collected from commercial shop in Dhaka City, Bangladesh following standard protocol (APHA 1998). All the samples were quickly transported to the laboratory. Prior to microbiological assay, $10 \mathrm{~g}$ of each sample was homogenized with $90 \mathrm{~mL}$ of distilled water 9:1 ratio and serially diluted in normal saline up to $10^{-3}$.

From the dilution $10^{-2}$ of each of the samples, 0.1 $\mathrm{mL}$ was introduced on to the nutrient agar and Sabouraud dextrose agar for the isolation of total viable bacteria and fungi, respectively. Subsequently, MacConkey agar, Membrane Fecal Coliform agar (MFC), Mannitol Salt agar, Pseudomonas agar, Starch agar and XLD agar were used as selective media for the quantification of coliforms, fecal coliforms, Staphylococcus spp., Pseudomonas spp. Bacillus spp. and Salmonella spp., respectively (Cappuccino and Sherman, 1996; Acharjee, Fatema, Jahan et al., 2013; Hassan et al., 2013 Acharjee et al., 2014). All the inoculated plates were incubated at $37^{\circ} \mathrm{C}$ for 24 hours except SDA plates, which were incubated at $25^{\circ} \mathrm{C}$ for 48 hrs.

\subsection{Taxonomic identification of the isolates}

The biochemical properties of identified isolates were confirmed through standard biochemical methods such as triple sugar iron test, motility test, indole production, methyl red reaction, Voges-Proskauer test, citrate utilization, catalase test and oxidase test (Cappuccino and Sherman, 1996; Islam et al., 2020).

\subsection{Antibiotic susceptibility test of the identified bacteria}

The pathogenic isolates were examined for antibiotic susceptibility traits (either drug resistant or sensitive) by using disc diffusion assay on Mueller-Hinton agar (Difco, Detroit, MI) against commonly used antibiotics following the standard protocol (Bauer et al., 1966; Ferraro, 2001; Nur et al., 2020). A thin layer of bacterial growth such as Escherichia coli, Pseudomonas spp., Vibrio spp., Staphylococcus spp. and Salmonella spp. (turbidity compared with the McFarland standard $\mathrm{OD}_{600^{-}}$ $0.5)$ were subjected to lawn on to surface of Muller Hinton agar. Antibiotics used in the study included polymyxin B (300 unit), kanamycin $(30 \mu \mathrm{g})$, methicillin $(30 \mu \mathrm{g})$, streptomycin $(10 \mu \mathrm{g})$, vancomycin $(30 \mu \mathrm{g})$, gentamycin $(10 \mu \mathrm{g})$, nalidixic acid $(30 \mu \mathrm{g})$, azithromycin $(15 \mu \mathrm{g})$, penicillin $\mathrm{G}(10 \mu \mathrm{g})$, erythromycin $(15 \mu \mathrm{g})$, amoxicillin $(30 \mu \mathrm{g})$, ceftriaxone $(30 \mu \mathrm{g})$, ciprofloxacin $(5$ $\mu \mathrm{g})$, ampicillin $(10 \mu \mathrm{g})$, tetracycline $(30 \mu \mathrm{g})$, chloramphenicol $(30 \mu \mathrm{g})$ and cefixime $(5 \mu \mathrm{g})$. All plates were incubated at $37^{\circ} \mathrm{C}$ for $12-18 \mathrm{hrs}$ and examined for formation of the zone of inhibitions (mm).

\section{Results and discussion}

\subsection{Microbial load in dessert samples}

All the samples were found to be contaminated with 
total viable bacteria (TVB) as well as fungi. In case of TVB the growth was estimated within the range of $10^{2}$ to $10^{5} \mathrm{CFU} / \mathrm{g}$ while the fungal contamination was noticed in between $10^{2}$ to $10^{4} \mathrm{CFU} / \mathrm{g}$ Table 1 ). The growth of Staphylococcus spp. was very high up to $10^{5} \mathrm{CFU} / \mathrm{g}$ in sweet, faluda, milk cake and ice cream, in halua and sweet yogurt $10^{4} \mathrm{CFU} / \mathrm{g}$ was found while rest of the samples exhibited up to $10^{3} \mathrm{CFU} / \mathrm{g}$. E. coli was found only in two samples faluda and ice-cream up to $10^{2} \mathrm{CFU} /$ $\mathrm{g}$ while Klebsiella spp. was estimated in all the samples within the range of $10^{2} \mathrm{CFU} / \mathrm{g}$ to $10^{5} \mathrm{CFU} / \mathrm{g}$. Salmonella spp., Pseudomonas spp. and Bacillus spp. were totally absent in all the samples. As described in many previous studies that the undesired microflora may transmitted in food samples during the processing of raw material, mixing of ingredients and packaging of the end products (Institute of Food Technologists, 2000; FAO and WHO, 2003; European Commission, 2004; Center for Food Safety and Applied Nutrition, (2008); Jane et al., 2018; FSANZ, 2001). According to the International Commission on Microbiological Specifications for Foods (ICMSF) 2011 the presence of specific pathogen in food should not be exceeded the marginal limit $10^{3}$ $\mathrm{CFU} / \mathrm{g}$. In this study, most dessert harbored excessive amount of Staphylococcal growth which exited the marginal limit provided by International Commission on Microbiological Specifications for Foods (ICMSF) 2011.

\subsection{Biochemical properties of the isolates}

All the isolates showed their physiological and metabolic activity through several biochemical tests (Table 2).

\subsection{Proliferation of drug-resistant bacteria in dessert food samples.}

To evaluate the efficacy of commonly available antibiotics as well as the clinical significance of the bacterial isolates, present study introduced antibiotic susceptibility test. Identified bacterial isolates were experimented to determine the antibiotic susceptibility against the commonly antibiotics. Most of the isolates were found to be resistant against most of the antibiotics, only streptomycin $(10 \mu \mathrm{g})$, gentamycin $(10 \mu \mathrm{g})$, azithromycin $(15 \mu \mathrm{g})$, and nalidixic acid $(5 \mu \mathrm{g})$ were effective drug against both E. coli and Staphylococcus spp. (Table 3).

As described in previous research that such drug resistance properties of bacteria may increases the host immunity as well as the beneficial role of host normal flora which can directly hinder the proper medication (Bennett, 2008; Acharjee, Jahan, Rahman et al., 2013). Several reasons are responsible to increases the bacterial resistance such as genetic alteration through mutation,

Table 1. Microbiological profiling of sampled dessert.

\begin{tabular}{lcccccccc}
\hline \multicolumn{1}{c}{ Sampled Dessert } & TVB & Fungi & E. coli & $\begin{array}{c}\text { Klebsiella } \\
\text { spp. }\end{array}$ & $\begin{array}{c}\text { Bacillus } \\
\text { spp. }\end{array}$ & $\begin{array}{c}\text { Pseudomonas } \\
\text { spp. }\end{array}$ & $\begin{array}{c}\text { Salmonella Staphylococcus } \\
\text { spp. }\end{array}$ & $\begin{array}{c}\text { spp. } \\
\text { Sweet }\end{array}$ \\
Faluda & $2.0 \times 10^{5}$ & $2.0 \times 10^{3}$ & 0 & $7.0 \times 10^{2}$ & 0 & 0 & 0 & $2.8 \times 10^{5}$ \\
Ice-cream & $4.0 \times 10^{5}$ & $2.7 \times 10^{3}$ & $3.7 \times 10^{2}$ & $5.0 \times 10^{5}$ & 0 & 0 & 0 & $4.3 \times 10^{5}$ \\
Pudding & $7.5 \times 10^{5}$ & $4.7 \times 10^{4}$ & $2.1 \times 10^{2}$ & $4.5 \times 10^{3}$ & 0 & 0 & 0 & $7.0 \times 10^{5}$ \\
Halua & $2.5 \times 10^{4}$ & 0 & 0 & $8.8 \times 10^{2}$ & 0 & 0 & 0 & $2.9 \times 10^{3}$ \\
Sweet yogurt & $2.0 \times 10^{4}$ & $2.1 \times 10^{3}$ & 0 & $6.0 \times 10^{5}$ & 0 & 0 & 0 & $2.8 \times 10^{4}$ \\
Mango Lassi & $2.0 \times 10^{3}$ & $1.5 \times 10^{2}$ & 0 & $4.8 \times 10^{2}$ & 0 & 0 & 0 & $2.5 \times 10^{4}$ \\
Tusha Haiwa & $3.0 \times 10^{3}$ & $2.0 \times 10^{3}$ & 0 & $4.4 \times 10^{3}$ & 0 & 0 & 0 & $2.3 \times 10^{2}$ \\
Lemon Curd & $4.0 \times 10^{5}$ & $2.0 \times 10^{3}$ & 0 & $2.5 \times 10^{3}$ & 0 & 0 & 0 & $2.0 \times 10^{3}$ \\
Egg Haloa & $2.0 \times 10^{3}$ & $1.5 \times 10^{2}$ & 0 & $3 \times 10^{2}$ & 0 & 0 & 0 & $2.3 \times 10^{3}$ \\
Fresh cheese dessert & $2.5 \times 10^{3}$ & $2.5 \times 10^{3}$ & 0 & $9.3 \times 10^{2}$ & 0 & 0 & 0 & $4.2 \times 10^{3}$ \\
Shemai & $2.0 \times 10^{3}$ & $2.0 \times 10^{3}$ & 0 & $4.5 \times 10^{3}$ & 0 & 0 & 0 & $2.7 \times 10^{2}$ \\
Bread pudding & $4.0 \times 10^{5}$ & $1.5 \times 10^{2}$ & 0 & $3.0 \times 10^{5}$ & 0 & 0 & 0 & $2.0 \times 10^{3}$ \\
Milk cake & $2.5 \times 10^{4}$ & 0 & 0 & $2.5 \times 10^{3}$ & 0 & 0 & 0 & $2.5 \times 10^{3}$ \\
Jellow fruit custard & $2.0 \times 10^{5}$ & $1.5 \times 10^{2}$ & 0 & $4.8 \times 10^{2}$ & 0 & 0 & 0 & $2.2 \times 10^{5}$ \\
Falooda & $2.0 \times 10^{3}$ & $1.5 \times 10^{2}$ & 0 & $6.0 \times 10^{5}$ & 0 & 0 & 0 & $2.5 \times 10^{2}$ \\
Cake & $3.0 \times 10^{2}$ & $2.7 \times 10^{3}$ & 0 & $2.0 \times 10^{2}$ & 0 & 0 & 0 & $4.2 \times 10^{3}$ \\
Ras malai & $2.0 \times 10^{3}$ & $1.5 \times 10^{2}$ & 0 & $3.0 \times 10^{5}$ & 0 & 0 & 0 & $3.0 \times 10^{2}$ \\
\hline
\end{tabular}

Table 2. Biochemical identification of the isolates

\begin{tabular}{|c|c|c|c|c|c|c|c|c|c|c|c|}
\hline \multirow{2}{*}{$\begin{array}{l}\text { Assumed Pathogenic } \\
\text { microorganisms }\end{array}$} & \multicolumn{4}{|c|}{ TSI } & \multirow{2}{*}{ Motility } & \multirow{2}{*}{ Indole Production } & \multirow{2}{*}{ MR } & \multirow{2}{*}{ VP } & \multirow{2}{*}{$\begin{array}{c}\text { Citrate } \\
\text { utilization }\end{array}$} & \multirow{2}{*}{ Catalase } & \multirow{2}{*}{ Oxidase } \\
\hline & Slant & Butt & Gas & $\mathrm{H}_{2} \mathrm{~S}$ & & & & & & & \\
\hline E.coli & $\mathrm{Y}$ & $\mathrm{Y}$ & + & - & + & + & + & - & - & + & - \\
\hline Klebsiella spp. & $\mathrm{Y}$ & $\mathrm{Y}$ & + & - & + & - & - & - & + & + & - \\
\hline Staphylococcus spp. & $\mathrm{Y}$ & $\mathrm{Y}$ & - & - & + & - & + & - & + & + & - \\
\hline
\end{tabular}

TSI: Triple Sugar Iron Test, Y: Yellow (Acid), R: Red (Alkaline), MR: Methyl red, VP: Voges-Proskauer 
Table 3. Antibacterial susceptibility test of the isolates

\begin{tabular}{|c|c|c|c|c|c|c|}
\hline \multirow[t]{2}{*}{ Antibiotic } & \multicolumn{2}{|c|}{$\begin{array}{l}\text { E. coli } \\
(\mathrm{n}=2)\end{array}$} & \multicolumn{2}{|c|}{$\begin{array}{l}\text { Klebsiella spp. } \\
\quad(\mathrm{n}=18)\end{array}$} & \multicolumn{2}{|c|}{$\begin{array}{c}\text { Staphylococcus spp. } \\
(\mathrm{n}=18)\end{array}$} \\
\hline & $\mathrm{R}(\%)$ & $\mathrm{S}(\%)$ & $\mathrm{R}(\%)$ & $\mathrm{S}(\%)$ & $\mathrm{R}(\%)$ & S (\%) \\
\hline Polymyxin B (300 unit) & 100 & 0 & 100 & 0 & 100 & 0 \\
\hline Kanamycin $(30 \mu \mathrm{g})$ & 100 & 0 & 100 & 0 & 100 & 0 \\
\hline Methicillin $(30 \mu \mathrm{g})$ & 100 & 0 & 100 & 0 & 100 & 0 \\
\hline Streptomycin $(10 \mu \mathrm{g})$ & 0 & 100 & 0 & 100 & 0 & 100 \\
\hline Vancomycin $(30 \mu \mathrm{g})$ & 100 & 0 & 100 & 0 & 100 & 0 \\
\hline Gentamycin $(10 \mu \mathrm{g})$ & 0 & 100 & 0 & 100 & 0 & 100 \\
\hline Nalidixic acid $(30 \mu \mathrm{g})$ & 0 & 100 & 0 & 100 & 0 & 100 \\
\hline Azithromycin $(15 \mu \mathrm{g}$ & 0 & 100 & 0 & 100 & 0 & 100 \\
\hline Penicillin G $(10 \mu \mathrm{g})$ & 100 & 0 & 100 & 0 & 100 & 0 \\
\hline Erythromycin $(15 \mu \mathrm{g})$ & 100 & 0 & 100 & 0 & 100 & 0 \\
\hline Amoxicillin $(30 \mu \mathrm{g})$ & 100 & 0 & 100 & 0 & 100 & 0 \\
\hline Ceftriaxone $(30 \mu \mathrm{g})$ & 100 & 0 & 100 & 0 & 100 & 0 \\
\hline Ciprofloxacin $(5 \mu \mathrm{g})$ & 100 & 0 & 100 & 0 & 100 & 0 \\
\hline Ampicillin $(10 \mu \mathrm{g})$ & 100 & 0 & 100 & 0 & 100 & 0 \\
\hline Tetracycline $(30 \mu \mathrm{g})$ & 100 & 0 & 100 & 0 & 100 & 0 \\
\hline Chloramphenicol $(30 \mu \mathrm{g})$ & 100 & 0 & 100 & 0 & 100 & 0 \\
\hline Cefixime $(5 \mu \mathrm{g})$ & 100 & 0 & 100 & 0 & 100 & 0 \\
\hline
\end{tabular}

$\mathrm{R}$ : resistant, $\mathrm{S}$ : sensitive

abuse of antibiotics, short-term drugs ingestion and easy access to get drugs from retailer without prescription (Canteón, 2009; Islam et al., 2020).

\section{Conclusion}

Cross-contamination of foods is one of the major concerns in the food industry, and if microorganisms are not completely removed from food-contact surfaces they may go on to form biofilms and increase the bio-transfer potential. In conclusion, this study demonstrates the presence of some pathogens including Staphylococcus spp., Klebsiella spp. and E. coli in dessert. Therefore, these foods are serious risk to the public health. Likewise, the presence of these organisms indicated that there were poor hygienic conditions during the manufacturing, storage and sales process of these traditional foods. Manufacturing procedures within the scope of the HACCP, appropriate hygienic measures to avoid pre-processing and post processing cross contamination and the use of pasteurized milk are critical to control such types of drug resistant pathogens in food samples. It is now very urge to find out the route of cross contamination in food (from raw material processing to final packaging) by which we can reduce such undesired growth of microorganisms in the food items.

\section{References}

Acharjee, M., Ahmed, E., Munshi, S.K. and Noor, R. (2014). Validation of $\gamma$-irradiation in controlling microorganisms in fish. Nutrition and Food Science, 44(3), 258-266.

Acharjee, M., Fatema, K., Jahan, F., Siddique, S.J.,
Uddin, M.A. and Noor, R. (2013). Prevalence of Vibrio cholerae in different food samples in the city of Dhaka, Bangladesh. International Food Research Journal, 20(2), 1017-1022.

Acharjee, M., Jahan, F., Rahman, F. and Noor, R. (2013). Bacterial proliferation in municipal water supplied in Mirpur locality of Dhaka city, Bangladesh. Clean - Soil, Air, Water, 42(4), 434441. https://doi.org/10.1002/clen.201200618

APHA (American Public Health Association). (1998). Standard methods for the examination of water and wastewater. Washington, D.C., USA: American Public Health Association.

Cappuccino J.G. and Sherman N. (1996). Microbiology A laboratory manual. Menlo Park, California: The Benjamin/Cummings Publishing Co. Inc.

Bauer, A.W., Kirby, W.M.M., Sherris, J.C. and Tierch, M. (1966). Antibiotic susceptibility testing by a standardized single disc method. American Journal of Clinical Pathology, 45(4), 493-496. https:// doi.org/10.1093/ajcp/45.4_ts.493

Bennett, J. W. and Klich, M. (2003). Mycotoxins. Clinical Microbiology Review, 16, 497-516. https:// doi.org/10.1128/CMR.16.3.497-516.2003

Canteón, R. (2009). Antibiotic resistance genes from the environment: a perspective through newly identified antibiotic resistance mechanisms in the clinical setting. Clinical Microbiology Infection, 15 (Supplement 1), 20-25. https://doi.org/10.1111/ j.1469-0691.2008.02679.x

Center for Food Safety and Applied Nutrition. (2008). Guide to Minimize Microbial Food Safety Hazards of Fresh-cut Fruits and Vegetables. USA: CFSAN. 
Danielsson-Tham, M.L., Eriksson, E., Helmersson, S., Leffler, M., Ludtke, L. and Steen, M. (2004). Causes behind a human cheese-borne outbreak of gastrointestinal listeriosis. Foodborne Pathogens and Disease, 1, 153. https://doi.org/10.1089/ fpd.2004.1.153

De Wijk, R.A., Van-Gemert, L.J., Terpstra, M.E.J. and Wilkinson, C.L. (2003). Texture of semisolids, sensory and instrumental measurements on vanilla custard desserts. Food Quality and Preference, 14 (4), 305-317. https://doi.org/10.1016/S0950-3293 (02)00107-6

European Commission. (2004). Hygiene of foodstuffs. Regulation (EC) No. 852/2004. Retrieved from Food Safety Authority of Ireland: https://www.fsai.ie/ uploadedFiles/Consol_Reg852_2004.pdf

FAO and WHO. (2003). Codex Alimentarius Commission. Report of the Thirty-Fifth Session of the Codex Committee on Food Hygiene. Alinorm 03/13A. Session of the Codex Committee on Food Hygiene. Orlando, Florida, USA: FAO and WHO.

FSANZ. (Food Standards Australia New Zealand). (2001). Microbiological Limits for Food with guidelines criteria. Retrieved from Food Standards Australia New Zealand website: http:// www.foodstandards.gov.au/publications/pages/ guidelinesformicrobi1306.aspx.

Ferraro, M.J., Craig, W.A. and Dudley, M.N. (2011). Performance standards for antimicrobial susceptibility testing. Pennsylvania, USA: NCCLS

González-Tomás, L. and Costell, E. (2006). Relation Between Consumers' Perceptions of Color and Texture of Dairy Desserts and Instrumental Measurements Using a Generalized Procrustes Analysis. Journal of Dairy Science, 89(12), 45114519. https://doi.org/10.3168/jds.S0022-0302(06) 72499-7

International Commission on Microbiological Specifications for Food (ICMSF). (1986). Microorganisms in food sampling for microbiological analysis: Principle and specific application. $2^{\text {nd }}$ ed. United Kingdom: Blackwell Scientific Publication.

Institute of Food Technologists. (2000). Kinetics of Microbial Inactivation for Alternative Food Processing Report. USA: FDA. Retrieved from website: https://www.fda.gov/files/food/published/ Kinetics-of-Microbial-Inactivation-for-AlternativeFood-Processing-Technologies.pdf

Islam, M.F., Nur, I.T., Islam, T., Sultana, R., Rezanujjaman, Md. and Acharjee, M. (2020). Microbiological status of some commonly available food items and the effects of microwave oven heat on the existence microflora. Food Research, 4(3), 697-702. https://doi.org/10.26656/fr.2017.4(3).376

Jane, T.N., Tabassum, N. and Acharjee, M. (2018). Study on the existence of food born microflora and their drug resistant profile isolated from some fermented and non-fermented foods commonly available in Bangladesh. Bangladesh Journal of Microbiology, 8(1), 19-23. https://doi.org/10.3329/ sjm.v8i1.42433

Hassan, M.R., Acharjee, M., Das, E., Das, K.K., Ahmed, T., Akond, M.A., Fatema, K.K. and Noor, R. (2013). Microbiological study of sea fish samples collected from local markets in Dhaka city. International Food Research Journal, 20(3), 1491-1495. https:// doi.org/10.1111/j.1750-3841.2000.tb00613.x

MacDonald, P.D.M., Whitwam, R.E., Boggs, J.D., MacCormack, J.N., Anderson, K.L., Reardon, J.W., Saah, J.R., Graves, L.M., Hunter, S.B. and Sobel, J. (2005). Outbreak of Listeriosis among Mexican immigrants as a result of consumption of illicitly produced Mexicanstyle cheese. Clinical Infectious Diseases, 40(5), 677-682. https:// doi.org/10.1086/427803

Makino, S.I., Kawamoto, K., Takeshi, K., Okada, Y., Yamasaki, M. and Yamamoto, S. (2005). An outbreak of food-borne Listeriosis due to cheese in Japan, during 2001. International Journal of Food Microbiology, 104(2), 189-196. https:// doi.org/10.1016/j.ijfoodmicro.2005.02.009

Meyer-Broseta, S., Diot, A., Bastian, S. and RiviereCerf, O. (2003). Estimation of low bacterial concentration: Listeria monocytogenes in raw milk. International Journal of Food Microbiology, 80(1), 1- 15. https:// doi.org/10.1016/S0168-1605(02)00117-4

Nur, I.T., Ghosh, B.K. and Acharjee, M. (2020). Comparative microbiological analysis of raw fishes and sun-dried fishes collected from the Kawran bazaar in Dhaka city, Bangladesh. Food Research, 4 (3), 846-851. https://doi.org/10.26656/fr.2017.4 (3). 368

Oliver, S.P., Jayarao, B.M. and Almeida, R.A. (2005). Food-borne pathogens in milk and the dairy farm environment: food safety and public health implications. Foodborne Pathogens and Disease, 2, 115. https://doi.org/10.1089/fpd.2005.2.115

Osamwonyi, O.U. (2005). Occurrence of coliforms in ice cream. Nigeria: University of Benin, BSc. Thesis.

U.S. Dairy Export Council (2001). An overview of changes in the characteristics, functionality and nutritional value of skim milk powder (SMP) during storage. Retrieved from website: http:// usdec.files.cms plus.com/PDFs/FoodAid/ SMPStorageFactShe et.pdf. 